\title{
クレイグ・エルウッドの住宅建築における空間構成材とモデュール SPACE AND ITS COMPOSITION OF CRAIG ELLWOOD'S RESIDENTIAL BUILDINGS FOCUSING ON MATERIAL AND MODULAR SYSTEM
}

\author{
増岡 亮*, 末包伸吾** \\ Ryo MASUOKA and Shingo SUEKANE
}

\begin{abstract}
This paper is an investigation, the type and its transformation of spatial composition in Craig Ellwood's residential buildings focusing on material and modular system. Analysis deals with 28 works and structure, primary exterior finishing materials, primary interior finishing materials, modular system on both plan and section. As a result of this analysis, following points are derived; In the 1950s, when standardization of construction lead to uniform spaces, Ellwood countered this trend by spatially arranging materials with texture in one modular system and controlling them with the exposed beams. Through this, he created an architecture that gave rhythm to space. In the 1960s, Ellwood used various column spans, defining the appearance of buildings by exposing beams and columns on the outside, making for compositions that gave rhythm to the outside.
\end{abstract}

Keywords : Craig Ellwood, Case Study House Program, Spatial Composition, Material, Modular System クレイグ・エルウッド, ケース・スタディ・ハウス・プログラム, 空間構成, 空間構成材, モデュール

\section{1. はじめに}

本考察注 ${ }^{1)}$ は，ケース・スタディ・ハウス (以下, CSH) \#16 (1952) \#17 (1956)＃18(1958)などにより, 第2 次世界大戦後のアメリカ西 海岸の建築を先導した建築家クレイグ・エルウッド (Craig E11wood, 1922-1992）の建築の特質を明らかにするため, 特に彼が主眼とした 独立住宅作品の空間構成の特徽を明らかにする研究の一部である. 前稿注 2) では, エルウッドの住宅建築の開放性に着目して, 主に配置 計画と平面計画の空間構成の特質を明らかにした.

エルウッドは, 1922 年にテキサス州に生まれ，1929 年にロス・ア ンゼルスに移住する．高校を卒業と同時に戦争による徵兵のため空 軍に従事する. 1945 年に終戦によりロス・アンゼルスにもどり建設 会社に勤務し, 当時西海岸で活躍していた建築家チャールズ・イー ムズやリチャード・ノイトラ, ラファエル・ソリアーノの仕事に携 わり，建築に関する知識や技術を習得する. 1948 年に会社を設立し， 同年にカリフォルニア大学ロサンゼルス校 (UCLA)に入学し, 構造力 学を専攻する. 1950 年代は, CSH プログラム (以下, CSHP) に参加し CSH\#16 を含む 3 作品やスミス邸 (1958), コーズン邸 (1959)等, 独 立住宅作品を主に設計する. 彼は CSHP の参加建築家の中でピエー ル・コーニッグらと共に第 3 世代注 ${ }^{3)}$ と着目され, 鉄骨を用いた作 品を創出した. 1960 年以降は, 交流のあったミース・ファン・デル・ ローエの影響を受け，独立住宅の他に事務所や商業施設，教育施設 等の設計を行い, アート・センター・カレッジ・オブ・デザイン (1975) 等の大規模な建築においても住宅と同様に鉄骨を用いた作品を創出
した。エルウッドは 1992 年に死去するまでに計画した建築作品は 98 件あり，このうち独立住宅作品は 58 件であった.

エルウッドの独立住宅から大規模施設にいたる建築作品の特徵は, 主に鉄骨を用いた架構形式注 4)を重んじた空間を創出しているとこ ろにある.これに関し, 彼は以下のように述べている.

Structure is the only clear principle. 注5)

構造はただ一つの明確な原則である.

エルウッドは, 構造力学に関する教育を受けた経歴から, 架構形 式とその技術によって創出される空間に関心をもち，それらによっ て空間に原則注 6)を与えることができると考えていた。また,この原 則については, 以下のように述べている.

Structure through technology is the only means to valid form. Materials and methods will certainly change, but the rules must be timeless. 注 7)

技術を通じた構造が正当な形態への唯一の手段である．材料や 方法は常に変化するが, 法則は時代を超越しなければならない.

このように,エルウッドは素材や工法は時間とともに変化するが, 空間に与えられる法則，つまり形態を導きだす基本的な原則は時間 とは関係なく不変であると考えていた。この原則は，架構形式によ
* 神戸大学大学院工学研究科 博士後期課程 (株) NTTファシリティーズ 修士 (工学)

** 神戸大学大学院工学研究科 教授·博士 (工学)
Grad. Stud., Graduate School of Engineering, Kobe University.

NTT FACILITIES, INC, M.Eng.

Prof., Graduate School of Engineering, Kobe University, Dr. Eng. 
って空間に一定のきまりを付与しょうとしていたと考えられよう. 本稿は, エルウッドの用いた空間構成材およびモデュールについて, それらの類型と経年的移行を明らかにすることで, 彼の架構形式を 重視した建築の特性の一端を示すことを目的とするものである.

エルウッドに関する既往研究は, 1990 年代にマッコイによるエル ウッドの作品を年代順に建築から家具のデザインまでを述べた書籍 注 8) や重要性に注視した作品集注 9) がある。ついで，2000 年代では， ジャクソンによるエルウッドの生涯を概括する書籍注 10) 注 11) やペレ スーメンデスによるエルウッドの主要な作品を述べた書籍注 ${ }^{12)}$ があ る. 我が国では, エルウッドについて CSHP に参加した第 3 世代の建 築家の一人として記述されることが多く注 ${ }^{13)}$ ，那須や山中らによる CSHP の研究注 14) では, CSH 全体の中でエルウッドの CSH\# 16, \# 17, \#18の3 作品を取り上げている.また, 前田と朽木注 ${ }^{15)}$ による CSH の一連の研究の中でエルウッドの作品の生成過程に着目した研究や, 宮下注 ${ }^{16)}$ による $\mathrm{CSH} \# 16$ の 1 作品の特質を示した既報や，平田注 ${ }^{17)}$ によるエルウッドの思想に着目した研究がある.このように CSH \# 16 での評価を中心にされてきたエルウッドについて, CSH の全体の 中で把握されるか一部の作品に着目した研究が多く, 筆者の見解で は CSH の作品だけでエルウッドの建築の特質を総括することは十全 とはいえない. 従って, 本研究が企図するようなエルウッドの活動 全てを通じてそれらの特質を類型的に把握し, その移行を含め総体 的に析出しようとするものは，未だ行われていないと考えられる.

\section{2. 分析の対象と方法}

筆者の調查注 ${ }^{18)}$ によると, エルウッドが計画した独立住宅作品は 58 件あり, このうち 38 件が実現し, 主に 1950 年代から 60 年代前 半に集中している. 本稿では, エルウッドの活動の中心であった独立 住宅作品に着目し, 分析にあたっては分析資料の踏査から分析資料
の完備しうる 28 作品 (表 1, 以降の表ではここに示した記号を用い る)を分析の対象とする.分析の基礎資料として筆者が現地調查やア 一カイブより収集したエルウッドの図面・写真注 ${ }^{19}$ や作品集注 20) より, 平面図と断面図を作成して第 1 次資料とした（図 1).

本稿では，エルウッドの空間構成材注 21$)$ とモデュールに着目し， 分析項目を以下の 5 点とした. (1)構造, (2)主な外部仕上材注 22), (3) 主な内部仕上材注 ${ }^{23)}$, (4)平面計画におけるモデュール, (5)断面計画 におけるモデュールである

3 章では, 空間構成材の特徴を把握する. エルウッドは上述した ように架構形式によって空間に原則を与えることができると考え， 構造と内外部の仕上材との関係を重視していた，そこで，構造に着 目して柱梁の種別や大きさと形状の分析を行いその関係を抽出し， さらに主な外部仕上材と公室空間注 ${ }^{24)}$ における主な内部仕上材を抽 出することで, 空間構成材の関係と経年的移行を分析する.

4 章では, エルウッドが用いた空間のモデュールを把握する. エ ルウッドの空間はある一定の原則により空間構成材を配置している と考えられる。そこで，平面計画における柱スパンと間仕切注 ${ }^{25)}$ の 配置とモデュールの関係を抽出し, ついで断面計画におけるモデュ ールを分析することで，エルウッドが用いたモデュールとその経年 的移行を明らかにする.

\section{3. 空間構成材}

エルウッドは建築の規格化に関心があったため, 空間構成におい て, 構造による一定のモデュールを採用し, 内外部の仕上材の使用 とその配置を行い, 空間を創出していると考えられる.このことから, 空間構成材は空間構成の重要な要素であるといえよう。本章では, 柱梁の種類や形状を分析し, 主な外部仕上材として外壁と外構注 26) を分析し，主な内部仕上材として公室空間に面寸る内壁と天井の仕

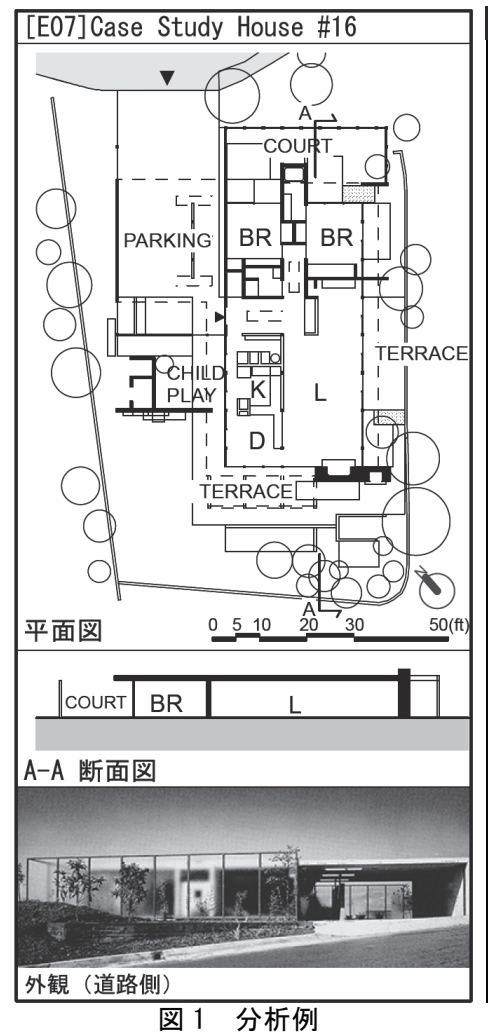

表 1 エルウッドの住宅建築における空間構成材

\begin{tabular}{|c|c|c|c|c|c|c|c|c|c|c|c|c|c|}
\hline \multirow{3}{*}{ 記号 } & \multirow{3}{*}{ 作品名 } & \multirow{3}{*}{$\begin{array}{l}\text { 竣 } \\
I \\
\text { 年 }\end{array}$} & \multicolumn{7}{|c|}{ 構造 } & \multicolumn{2}{|c|}{ 主な外部仕上材 } & \multicolumn{2}{|c|}{ 主な内部仕上材 } \\
\hline & & & \multirow{2}{*}{$\begin{array}{l}\text { 構造 } \\
\text { 種別 }\end{array}$} & \multicolumn{3}{|c|}{ 柱 } & \multicolumn{3}{|c|}{ 梁 } & \multirow{2}{*}{ 外壁 } & \multirow{2}{*}{ 外構 } & \multirow{2}{*}{ 内壁 } & \multirow{2}{*}{ 天井 } \\
\hline & & & & 素材 & 形状 & 大きさ & 素材 & 形状 & 大きさ & & & & \\
\hline$[\mathrm{E} 01]$ & Lappin House(ラッピン邸) & 1948 & $\mathrm{M}$ & $\mathrm{s}$ & - & - & W & - & - & $B \cdot C$ & - & C & $\mathrm{C}$ \\
\hline$[\mathrm{E} 02]$ & Epstein House (エプスタイン邸) & 1949 & $M$ & $\mathrm{~s}$ & A & - & W & $\mathrm{c}$ & - & $B \cdot C$ & $E$ & $\mathrm{C}$ & $\mathrm{C}$ \\
\hline$[\mathrm{E} 03]$ & Zimmerman House (ツインマーマン邸) & 1950 & $\mathrm{M}$ & $\mathrm{s}$ & A & - & $\mathrm{w}$ & $\mathrm{C}$ & - & $A \cdot C$ & $E$ & C & \\
\hline$[E 04]$ & Broughton House(ブロートン邸) & 1950 & M & $\mathrm{s}$ & $\mathrm{C}$ & $3 \times 6$ & W & $\mathrm{C}$ & - & $A \cdot B$ & $E$ & $\mathrm{C}$ & $B$ iो $C$ \\
\hline$[\mathrm{E} 05]$ & Heller House(ヘラー邸) & 1951 & $\mathrm{~s}$ & $\mathrm{~s}$ & $B$ & $5 \times 5$ & $\mathrm{~s}$ & $\mathrm{~B}$ & - & $\mathrm{C}$ & - & $\mathrm{C}$ & \\
\hline$[E 06]$ & Hale House (ヘール邸) & 1951 & M & $\mathrm{s}$ & $B$ & $4 \times 4$ & W & $\mathrm{C}$ & $4 \times 10$ & $\mathrm{C}$ & $A \cdot E$ & $B \cdot C$ & $B$ मे $\mathrm{C}$ \\
\hline$[\mathrm{E} 07]$ & Case Study House \#16 & 1953 & $\mathrm{~s}$ & $\mathrm{~s}$ & A & $2.5 \times 2.5$ & $\mathrm{~s}$ & $\mathrm{~B}$ & $2.5 \times 6$ & $B \cdot D \cdot F$ & $E$ & $B \cdot C \cdot D$ & $C$ 放 $\mathrm{C}$ \\
\hline$[E 08]$ & Zack House(ザック邸) & 1952 & $\mathrm{~s}$ & $\mathrm{~s}$ & $\mathrm{~B}$ & $4 \times 4$ & W & $\mathrm{C}$ & - & $A \cdot C$ & $E$ & $A \cdot C$ & $B$ iो $C$ \\
\hline$[E 09]$ & Johnson House (ジョンソン邸) & 1953 & M & $\mathrm{s}$ & $B$ & $4 \times 4$ & W & $\mathrm{C}$ & $4 \times 10$ & $\mathrm{~B}$ & $E$ & $B \cdot C$ & $B$ it $C$ \\
\hline$[\mathrm{E} 10]$ & \begin{tabular}{|l|l|l|l} 
First Pierson House (ピアソン) \\
\end{tabular} & 1953 & M & $\mathrm{s}$ & $B$ & $4 \times 4$ & $\mathrm{~W}$ & $\mathrm{C}$ & - & $B \cdot C$ & $B$ & $B \cdot C$ & $B$ 击 $\mathrm{C}$ \\
\hline$[\mathrm{E} 11]$ & Andersen House(アンデルセン邸) & 1954 & $\mathrm{w}$ & $\mathrm{w}$ & $\mathrm{C}$ & $3 \times 6$ & $\mathrm{w}$ & $\mathrm{C}$ & $3 \times 12$ & $A \cdot C$ & $\mathrm{D}$ & $A \cdot C$ & $B$ it $C$ \\
\hline$[\mathrm{E} 12]$ & Case Study House\#17 & 1956 & $\mathrm{~s}$ & $\mathrm{~s}$ & $\mathrm{~B}$ & $4 \times 4$ & $\mathrm{~s}$ & $\mathrm{~B}$ & $4 \times 5$ & $A \cdot B$ & $E$ & $A \cdot B$ & $\mathrm{~B} \quad \mathrm{C}$ \\
\hline$[\mathrm{E} 13]$ & Carlson House(カールソン邸) & 1956 & M & $\mathrm{s}$ & $B$ & $4 \times 4$ & W & $\mathrm{C}$ & - & $B \cdot C$ & $B$ & $A \cdot B$ & $\mathrm{~B}$ 放 $\mathrm{x}$ \\
\hline [E14] & Steinman House(スタインマン邸) & 1956 & M & $\mathrm{s}$ & $\mathrm{C}$ & $3 \times 6$ & W & $\mathrm{C}$ & - & $A \cdot C$ & $E$ & $A \cdot B \cdot C$ & $\mathrm{~B}$ है $\mathrm{C}$ \\
\hline [E15] & House in Sherman Oaks (シャーマン邸) & 1956 & M & $\mathrm{s}$ & $\mathrm{C}$ & $3 \times 6$ & $\mathrm{~W}$ & $\mathrm{C}$ & - & $B \cdot C$ & $\mathrm{E}$ & $B \cdot C$ & $B$ iो $C$ \\
\hline [E16] & Kuderna House(クデルナー邸) & 1956 & $\mathrm{~s}$ & $\mathrm{~s}$ & $\mathrm{~B}$ & $4 \times 4$ & $\mathrm{~s}$ & $\mathrm{~B}$ & - & $B \cdot C$ & $\mathrm{E}$ & $B \cdot C$ & \\
\hline [E17] & Hunt House(ハント邸) & 1957 & $\mathrm{~s}$ & $\mathrm{~s}$ & $\mathrm{C}$ & $3 \times 6$ & $\mathrm{~s}$ & $\mathrm{C}$ & $3 \times 14$ & $\mathrm{C}$ & $\mathrm{B}$ & $B \cdot C$ & $B$ iो $\mathrm{C}$ \\
\hline [E18] & Smith House (スミス邸) & 1958 & $\mathrm{~s}$ & $\mathrm{~s}$ & A & $4 \times 4$ & $\mathrm{~s}$ & $\mathrm{~B}$ & $6 \times 4$ & $\mathrm{C}$ & $\mathrm{B}$ & $A \cdot C$ & \\
\hline [E19] & Case Study House \#18 & 1958 & $\mathrm{~s}$ & $\mathrm{~s}$ & A & $2 \times 2$ & $\mathrm{~s}$ & $\mathrm{C}$ & $2 \times 51 / 2$ & $\mathrm{C}$ & $\mathrm{E}$ & $B \cdot C$ & $B$ iो $x$ \\
\hline$[\mathrm{E} 20]$ & Korsen House (コーズン邸) & 1959 & $\mathrm{~s}$ & $\mathrm{~s}$ & $B$ & $4 \times 4$ & $\mathrm{~s}$ & $\mathrm{~B}$ & - & $\mathrm{C}$ & $E$ & $B \cdot C$ & \\
\hline$[\mathrm{E} 21]$ & Daphne House(ダフニ邸) & 1961 & $\mathrm{~s}$ & $\mathrm{~s}$ & $B$ & $6 \times 6$ & $\mathrm{~s}$ & $\mathrm{C}$ & - & $D \cdot F$ & $E$ & $B \cdot C$ & \\
\hline$[\mathrm{E} 22]$ & Rosen House (ローズン邸) & 1963 & $\mathrm{~s}$ & $\mathrm{~s}$ & $B$ & $6 \times 6$ & $\mathrm{~s}$ & $\mathrm{~B}$ & - & $A \cdot F$ & $\mathrm{D}$ & $A \cdot B \cdot C$ & \\
\hline [E23] & Moore House (ムーア邸) & 1965 & $\mathrm{~W}$ & $\mathrm{w}$ & A & $6 \times 6$ & $\mathrm{~s}$ & $\mathrm{~B}$ & $4 \times 12$ & $B \cdot F$ & - & $\mathrm{C}$ & $\mathrm{C}$ \\
\hline [E24] & Kubly House(クブリー邸) & 1965 & $\mathrm{~W}$ & $\mathrm{w}$ & A & $6 \times 6$ & $\mathrm{~W}$ & $\mathrm{C}$ & $3 \times 12$ & $\mathrm{~F}$ & - & $\mathrm{C}$ & $\mathrm{C}$ \\
\hline [E25] & Goldman House(ゴールドマン邸) & 1968 & $\mathrm{~s}$ & $\mathrm{~s}$ & $\mathrm{~B}$ & - & $\mathrm{s}$ & $\mathrm{C}$ & - & $A \cdot F$ & $\mathrm{E}$ & - & - \\
\hline [E26] & Palevsky House(パレブスキー邸) & 1969 & $\mathrm{~s}$ & $\mathrm{~s}$ & $\mathrm{~B}$ & - & $\mathrm{s}$ & $\mathrm{B}$ & - & $A \cdot F$ & A & $A \cdot B$ & \\
\hline [E27] & Kawahara House(カワハラ邸） & 1970 & $\mathrm{~s}$ & $\mathrm{~s}$ & $\mathrm{~B}$ & - & $\mathrm{s}$ & B & - & $\mathrm{F}$ & $\mathrm{E}$ & $\mathrm{C}$ & $G$ 许 \\
\hline \multirow[t]{4}{*}{ [E28] } & Harris House(ハリス邸) & 1972 & $\mathrm{~s}$ & $\mathrm{~s}$ & $B$ & - & $\mathrm{s}$ & $\mathrm{B}$ & - & $A \cdot F$ & - & $A \cdot C$ & \\
\hline & & & & \multicolumn{2}{|c|}{ 素材の凡例 } & \multicolumn{2}{|c|}{ 素材形状の凡例 } & \multirow{3}{*}{\multicolumn{2}{|c|}{$\begin{array}{l}\text { ※柱梁の大きさの } \\
\text { 単位はインチととす } \\
\text { る. }\end{array}$}} & \multicolumn{3}{|c|}{ 内外部の仕上材の凡例 } & 延長の有無 \\
\hline & & & S:鉄骨造 & \multirow{2}{*}{\multicolumn{2}{|c|}{$\begin{array}{l}\text { S: 鉄骨 } \\
\text { w:木 }\end{array}$}} & \multirow{2}{*}{\multicolumn{2}{|c|}{$\begin{array}{l}\text { A:正方形 } \\
\text { B:H型/型 } \\
C: \text { 長方形 }\end{array}$}} & & & A:Lンガ & D:石 & G:パネル & ○:延長あし \\
\hline & & & $\begin{array}{l}\text { W: 木造 } \\
\text { M:湿構造 }\end{array}$ & & & & & & & $\begin{array}{l}\mathrm{B}: \text { 木 } \\
\mathrm{C}: \text { プラスター }\end{array}$ & $\begin{array}{l}E: \text { コンクリ } \\
F: \text { ガラス }\end{array}$ & $-r$ & 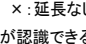 \\
\hline
\end{tabular}


上材を分析をすることにより空間構成材の関係を把握し,それらの 経年的移行を抽出することで，その特質を明らかにする.

表 1 は，分析対象作品の空間構成材を整理したものである．以下 では,この表に基づき分析を行う.

\section{3-1. 構造（図 2)}

前述した「構造はただ一つの明確な原則である」注 27) と述べるよ うに，エルウッドの言説注 ${ }^{28)}$ には構造に関する記述が多く, 彼は空 間構成材の中でも, 特に構造を重要視していることがうかがえる.

Nature is simple, but unfortunately it does not simplify. It is up to us to search for this simplicity, to express logic and clarity, and to understand structure. 注29)

自然は単純である。しかし残念なことに, それは単純化しない。 この単純さを求め, 論理と明快さを表現し, 構造を理解すること は，我々次第である.

このように，エルウッドは構造を自然の原理にたとえ，単純化し， 論理的でかつ明快さを兼社備えることが重要であると考えていた. ここでは，架構形式の主軸を担る柱梁に着目して分析を行った。

（1）柱：<鉄骨 >が 25 件，<木>が 3 件である. <鉄骨 $>$ の形状 は正方形が 5 件, 長方形が 4 件, H 型が 15 件である. <木 >の形状 は正方形が 2 件, 長方形が 1 件である. また, 柱の大きさをみると, 正方形の柱は主に《 2.5 インチ $\times 2.5$ インチ》（以下，柱梁の大きさ はインチ表記とし単位は省略する) 《 $2 \times 2\rangle\langle 4 \times 4\rangle$, 長方形の柱は《 $《 3$ $\times 6\rangle, \mathrm{H}$ 型の柱は《 $4 \times 4 \times\langle\langle 6 \times 6\rangle$ である.エルウッドは, 50 年代は

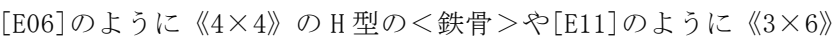
の<木 $>$ を用い, 外部空間に面する開口部では素材に関わらず柱を サッシュと同色とすることにより柱の存在感を消している. 60 年代 は[E21]のように柱を《《6×6》》の H 型の<鉄骨 $>$ や[E24]のように正 方形のく木>を用い, 柱とサッシュを差別化することで明確に柱を 表出させる構成へと移行している.

（2）梁：＜鉄骨＞が 15 件，〈木>が 13 件である.また，〈鉄骨＞ の形状は, 長方形が 4 件, I 型が 11 件である. 梁の大きさをみると, 梁成は素材による耐力とスパンに関わり，〈木>は主に《4×10～12》 $\langle 3 \times 12 \sim 14\rangle, \quad<$ 鉄骨 $>$ は $\langle 2.5 \sim 4 \times 6\rangle\langle 3 \sim 4 \times 12\rangle$ である. エル ウッドは, 50 年代はく木>を多用し, それらを内部空間に表出させ る構成が多く, 60 年代は主に<鉄骨 >を用い, 内部空間に表出させ ず，外部に表出させる構成へと移行している.

(3) 構造種別 : 以上の柱梁の検討のもと, それらが組合わされる構 造種別をみると, [E13]のように柱を<鉄骨 $>$ 梁をく木 $>$ とする混構 造が 10 件，[E22]のように柱梁を<鉄骨＞とする鉄骨造が 15 件, [E23]のように柱梁をく木>とする木造が 3 件である. 経年的移行を みると, 50 年代前半は柱を $《 4 \times 4\rangle$ の $\mathrm{H}$ 型の $<$ 鉄骨 $>$, 梁を $<$ 木 $>$ とする混構造となり, 内部空間に梁を表出させる構成である. 50 年 代中盤から 60 年代にかけて柱を《 $4 \times 4$ \または《 $46 \times 6 》 の \mathrm{H}$ 型の< 鉄骨 $>$, 梁を $<$ 鉄骨 $>$ とする鉄骨造が多くなり，外部に柱梁を表出 させる構成が試行される. 60 年代以降は＜鉄骨 $>0$ 柱梁が大きくな り，外部に明確に表出させる構成へと移行している。その中 で, [E23] [E24]の 2 つの作品は, 55 年以降で数少ない木造である. 計画時は鉄骨造であったが, 物価高騰にともなうコスト削減のため,
木造に計画変更を行っている.この構造変更があったにも関わらず, 鉄骨造のように柱梁を表現しているところに，エルウッドの柱梁の 構造への強い意欲と技術力の高さがうかがえる.

\section{3-2. 外部仕上材（図 3)}

（1）外壁の仕上材：仕上材の組合せは 1 種類のみが 9 件， 2 種類が 18 件, 3 種類が 1 件である. 1 種類のみの作品は, <プラスター> が 6 件，〈ガラス >が 2 件，〈木>が 1 件である. 外壁が<ガラス $>$ のみは，[E27]のように全周を<ガラス $>$ とする作品である．2 種 類の組合せは，〈プラスター+木>が 6 件，〈プラスター+レンガ $>$ が 4 件，〈ガラス+レンガ $>$ が 4 件，＜ガラス+木 >が 1 件，＜ガラ ス+石 >が 1 件，〈レンガ+木>が 2 件である. 3 種類の組合せは， <ガラス+石+木＞が 1 件である. 2 種類および 3 種類の組合せで< ガラス >を用いる作品は, [E28]のように外周の半分以上を $<$ ガラス >とし, 50 年代後半から徐々に<ガラス >を使用する割合が増えて いる. 経年的移行をみると, 50 年代前半はくプラスター>を基調に, [E07］のように<木>，[E14]のように<レンガ>を併用する事例が 多く，〈木 $><$ レカガ $>$ 塗装しない素地で用いることで, <プラ スター>に対して素材感のある構成である. 50 年代後半は, <プラ スター>のみを用いる事例が多く，〈ガラス >を用いる割合が増加 し始める. 60 年代は [E28]のように構造を鉄骨とすることでくガラ ス>を基調に，一部に<木 $>$ やレンガ >を使用する事例が多く， 素材感を抑えた構成である。このように外部仕上材は, 混構造から 鉄骨造に変化することによって，＜プラスター＞を基調に複数の仕 上材の組合せによる素材感のある構成からくガラス $>$ 基調に<プ ラスター>による素材感を抑えた構成へと移行している.

(2) 外構の仕上材:<コンクリート>の平板を用いたものが 15 件, <木>が 4 件，〈石 >が 2 件，〈その他 >が 2 件である. 公室空間 に接する外部空間の床材は各年代ともに主にくコンクリート>の平
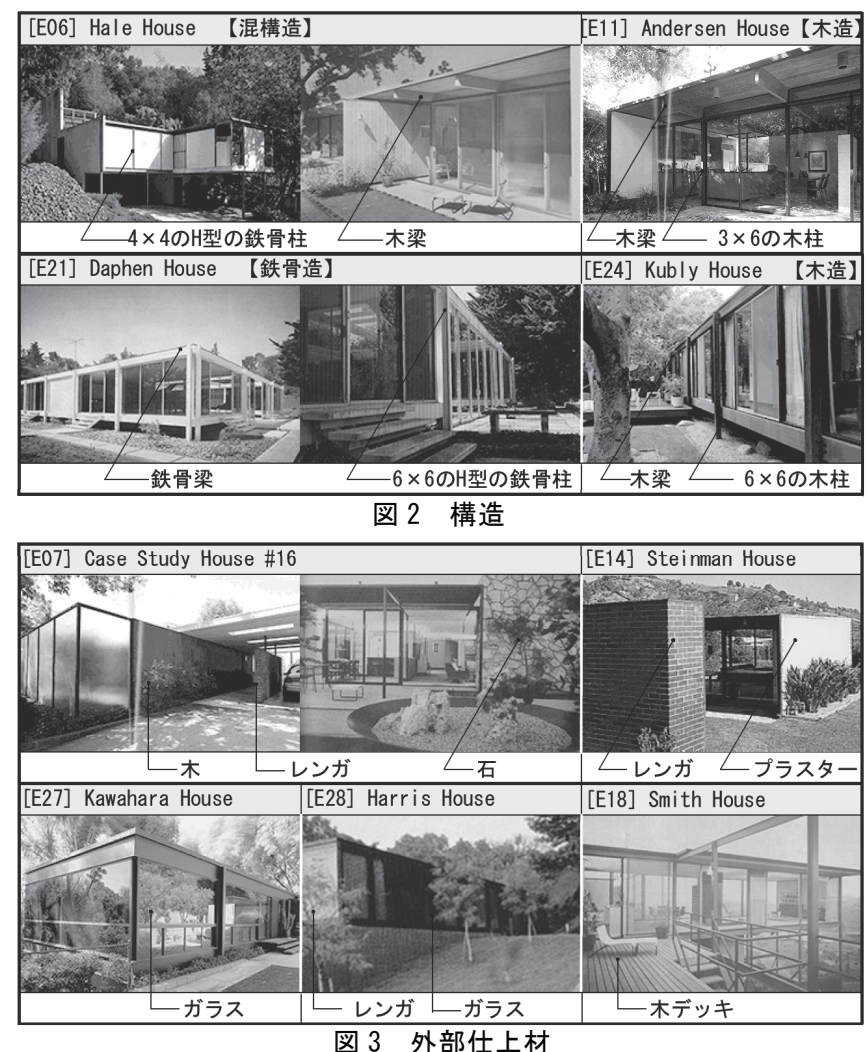
板を用いている. 50 年代の工事費をおさえた住宅作品にとって安価 なコンクリート平板を用いた計画は有効な手段であった。また，く 木>は[E18]のように傾斜地に計画され，外部の床材を<木>とし， 屋内と屋外を連続する構成である. 60 年代以降は, 1 階と外部空間 を $3 \mathrm{ft}$ のレベル差を設け, 周囲を砂利等で仕上げる構成が多い.

\section{3-3. 内部仕上材（図 4, 図 5)}

（1）天井の仕上材 : <プラスター>が 14 件，〈木>が 12 件，<プ レート>が 1 件である. 天井を屋外に延長している作品は 13 件あり, このうちくプラスター>が 3 件, <木 $>$ が 10 件である. 天井は屋外 に延長しない<プラスター>, または屋外に延長するく木 $>$ とする ことが多い. 経年的移行をみると， 50 年代前半まではくプラスター >のみの単調な仕上とし，屋内から屋外に天井を延長している. 50 年代前半から 50 年代後半までは, [E13] のように屋根の素材である <木>現しとし, 天井に梁を表出させ, 屋内から屋外に天井と梁を 延長している．また，[E07］のように天井にくプラスター>を使用 しながら梁底を表出させている，この年代では，エルウッドは空間 に梁を表出させることを企図していることがうかがえる. 60 年代は, [E26]のように梁を隠すように天井をくプラスター>とし, 屋外に 延長をしない構成へと移行している.

（2）内壁の仕上材：<プラスター>のみが 8 件， 2 種類の組合せが 16 件, 3 種類の組合せが 3 件である. 2 種類以上の組合せをみると, <プラスター+木 $>$ が 9 件，＜プラスター+レンガ $>$ が 4 件，＜レン ガ+木 >が 3 件である. 3 種類の組合せは，〈プラスター+レンガ+木 $>$ が 2 件，〈プラスター+木+石 >が 1 件である. 内壁は<プラスタ 一>を基調に, 〈木 $>$ やくンガ >を塗装のない素地で併用し, 素 材感のある構成としている. また，〈木>の使用は[E15]のように木 幅で目地ありから[E26]のように木パネルで目地なしとする素材感 を抑える構成に変化している. 経年的移行をみると, 50 年代前半ま では<プラスター>のみが用いられ，50 年代前半から徐々に<プラ スター>を基調に, [E22]のように<レンガ $>$ アく $>$ を併用するよ

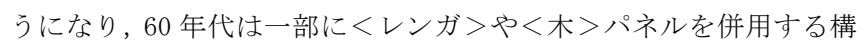
成へと移行している。

\section{3-4. 空間構成材の関係とその移行}

前節までで空間構成材として, 柱梁, 外部仕上材, 内部仕上材の 分析を行った.ここでは空間構成材の関係とその経年的移行をみる. 50 年代前半までは, 天井をくプラスター>とし, 内外壁にくプラス ター>を基調に，〈木>やくレンガ >を併用しする構成である. 50 年代前半から後半にかけて, 内外壁の構成は変わらず, 天井を<木 $>$ とし梁の <木 $>$ を表出させることで, 素材感のある構成に変化し ている. 60 年代は柱梁に $<$ 鉄骨 $>$ を用い, 外壁にくガラス $>$ を基調 に，一部に<レンガ $>$ や木 $>$ を併用することで, 内部は素材感を 抑えた構成とし, 外部に柱梁を表出させる構成へと移行している. エルウッドは架構形式の変化に伴い, 内部に梁を表出させ様々な仕 上材の組合せによる素材感のある空間構成から, 外部に柱梁を表出 させ主に＜鉄骨 $>$ と<ガラス $>$ にる素材感を抑えた空間構成に移 行していることが明らかになった。

\section{4. モデュール}

エルウッドは建築の規格化とその技術について関心があり，それ らを企図した多くの作品を生み出してきた。規格化による構成は一
定のモデュールを用いることで空間構成材を統御することと考えら れよう。また, 空間構成材について, 言説のなかで装飾注 30$)$ といい, それらを統合する必要性を述べている。

Man has always decorated his structures, and there is a need for integrated decoration. 注31)

人は構築物を常に装飾してきた，そしてそこには統合された装飾 の必要性がある。

そこで，エルウッドは，この装飾である空間構成材を統合する方 法として, 空間構成材の各要素がもたらすリズム注 $\left.{ }^{32}\right)$ が重要である と考え, 以下のように述べている.

I say rhythmic because rhythm is the fundamental in all design, whether natural or man-made. 注 ${ }^{33)}$

リズムは自然物や人工物に関わらず，全てのデザインにおいて基 本であるため，私はリズムについて言及している.

このように，エルウッドは空間を構成するうえでリズムを基本と し，空間構成材を配置しているといえよう。彼は空間にリズムを持 ち込むことで，規格化による画一化となる空間に対して多様な空間 を創出し空間に個別性をもたらすことを企図していたと考えられよ う。本章では，エルウッドのモデュールについて，平面図と断面図 注 34) にモデュールを重祇合わせて分析図(図 6)を作成し, 整理したも のが表 2 である．以下では，この表に基づいてモデュールの分析を 行い，経年的移行を抽出することで，その特質を明らかにする.

\section{4-1. 平面計画のモデュール（図 7)}

平面計画のモデュールについて, 柱スパンと間仕切の 2 つに分類 する．柱スパンは $<8 \mathrm{ft}>$ が 15 件，<10ft $>$ が 2 件，〈その他 $>$ が 12 件である. 間仕切は $<4 \mathrm{ft}>$ が 15 件， < $5 \mathrm{ft}>$ が 2 件，<その他 $>$ が 12 件である. エルウッドは柱スパンを $<8 \mathrm{ft}>$ とし, 間仕切を $<4 \mathrm{ft}>$ とすることが多い. 経年的移行をみると，50 年代は [E11]の ように柱スパンを $<8 \mathrm{ft}>$ ，間仕切を $<4 \mathrm{ft}>$ とする事例が多い，当 時の社会状況による経済性かつ工事における施行の合理性から部材 の規格化に着目していたため一定のモデュールとして $<8 \mathrm{ft}>$ と $<$ $4 \mathrm{ft}>$ を採用し続けたことがうかがえる. 60 年代は [E22]の柱スパン は＜26ft8in>, 間仕切は＜3ft4in>で配置するように, 柱スパンを

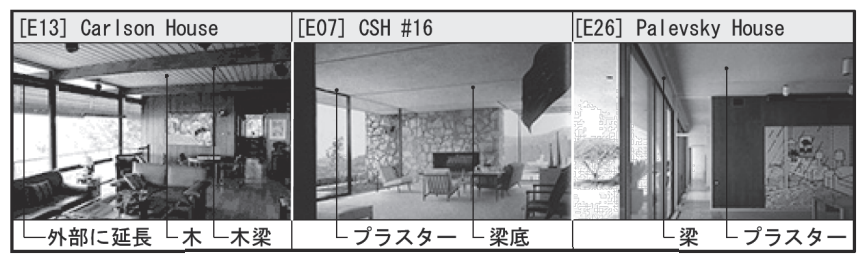

図 4 天井の仕上材

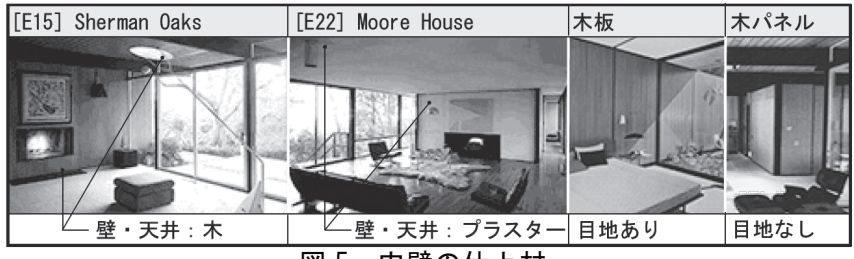

図 5 内壁の仕上材 
<9ft 以上>とし, 間仕切は柱スパンを均等に分割するモデュール へと移行している。これらは鉄骨等の資材の普及により規格化され た部材を用いる必要がなくなったことから, 柱梁スパンを自由に設 定でき，モデュールが変化したことがうかがえる．

\section{4-2. 断面計画のモデュール（図 7, 図 8)}

断面計画のモデュールについて，＜8ft $>$ を基準として， [E22]の ようにサッシュの天端と天井高さが一致する作品が 10 件, [E11]の ようにサッシュの天端を $<8 \mathrm{ft}>$ とし梁の表出による梁成だけ天井 が高い作品が 12 件, < $8 \mathrm{ft}>$ 以上の作品が 3 件である. 50 年代後半 までは, サッシュの天端を $<8 \mathrm{ft}>$ とし, キッチン等の腰壁の高さ, 家具等の高さ, 間仕切高さを梁下に抑え, 高さ方向を分割している. このような計画とすることで, エルウッドは明確に梁の表出を企図 していることがうかがえる. 50 年代後半から 60 年代は, 各要素に よる高さの分割を行わず, $<8 \mathrm{ft}>$ を基準とする平滑な断面計画であ る.特に 60 年代の一部の作品において 1 階の床レベルを $3 \mathrm{ft}$ 持ち上 げることで，建物高さを変化させていることが特徵である.

\section{4-3. モデュールの特徵とその移行} た.ここではモデュールの特徵とその経年的移行をみる. 50 年代は 柱スパンを $<8 \mathrm{ft}>$, 間仕切を $<4 \mathrm{ft}>$ を採用して間仕切を規則的に 配置し, 断面はサッシュ天端の $<8 \mathrm{ft}>$ を基本とし, 家具等によって
前節までで平面計画と断面計画のモデュールについて分析を行っ

高さを分割し，一定のモデュールにより梁を表出させることで，内 部空間にリズムを企図した構成である. 60 年代は柱スパンに< $\mathrm{fft}$ 以上>を採用し，間仕切は柱スパンを均等に分割した $<3 \sim 4 \mathrm{ft}>$ と する. 断面は＜8ft $>$ の定の高さとし，外部に柱梁を表出して住宅 の骨格をつくることで内部空間を規制し，外部にリズムを表現する ことを企図した構成に移行していることが明らかになった。

\section{5. まとめ}

本研究では，エルウッドの空間構成材について，構造，外部仕上 材，内部仕上材およびそれらを統御する平面計画と断面計画のモデ ユールの分析を行うことで，それらの関係と経年的移行を明らかに してきた．分析の結果を整理したものが表 3 である.

エルウッドの空間構成材とモデュールは，50 年代と 60 年代で大 きく 2 つの傾向をとる.

50 年代は, 柱をく鉄骨 >, 梁をく木>とする混構造を主に採用し, 内外部の仕上材は＜プラスター >を基調にくレンガ $><$ 木 $>$ とし， 天井は屋根材であるく木>現しとして梁を表出させ，素材感のある 空間の創出を企図していると考えられる。モデュールは柱スパンを $<8 \mathrm{ft}>$, 間仕切を $<4 \mathrm{ft}>$ とし, 天井高さはサッシュの天端の $<8 \mathrm{ft}$ $>$ を基準に, 建具や家具, 間仕切等の高さで分割している.このよ うに素材感のある内部空間において, サッシュの素材や高さに変化

表 2 平面・断面モデュール



図 7 モデュールの分析図 
をつけることで, 明確に梁が認識できるような構成とし, さらに内 部から外部に延長しているところに特徵がある. 天井に梁を表出さ せることで空間に一定のリズムを与えているといえよう．

60 年代に入ると, 柱梁を $<$ 鉄骨 $>$ とする鉄骨造とし, 外部仕上材 はくガラス $>$, 内部仕上材はくプラスター >を基調とし, 一部に $<$ レンガ $><$ 木を用いることで, 素材感を抑えた空間の創出を企図 していると考えられる. モデュールは柱スパンを $<9 \mathrm{ft}$ 以上 $>$ と それらを均等に分割するように間仕切を配置している．柱梁による 大スパンを採用しかつそれらを外部に表出させることで, 外郭に一 定のリズムを与えているといえよう.

以上より, エルウッドの空間構成材とモデュールは, 50 年代は建 築の規格化による画一的な空間に対して, 素材感のある空間構成材 をひとつのモデュールに沿って配置し, それらを統御するように梁 を表出させることで, 空間にリズムを与える構成である. 60 年代は 規格化に関わらず様々な柱梁のスパンを採用し, 外部に表出させる
ことで建物の外郭を決定し，外部にリズムを与える構成である.つ まり，エルウッドの架構形式は架構を表出させる構成を内部から外 部に移行し，それによってモデュールを認識させ空間にリズムをも たらしていることから, 空間創造の原則を移行しているといえよう.

このように, 本研究では空間構成材とモデュールに着目して分析 を行い，それらによって成立する架構形式が一定のリズムをもたら し, 空間を構成していることが明らかになった，今後はエルウッド の架構形式を詳細に分析することで彼の空間の原則とその特質を明 らかにすることができよう。

\section{参考文献}

1) Esther McCoy: Case StudyHouse1945-1962,Hennessey\&Ingalls, 1962

2) Esther McCoy: CRAIG ELLWOOD, Hennessey \& Ingalls, 1997

3) Craig Ellwood 15 House, 2G(Gustavo Gili), no.12, 1999

4) Neil Jackson: Craig Ellwood, Laurence King Publishing, 2002

5) Neil Jackson: CALIFORNIA MODERN The Architecture of Craig Ellwood, Princeton Architectural Press, 2001

表 3 空間構成材とモデュールの移行

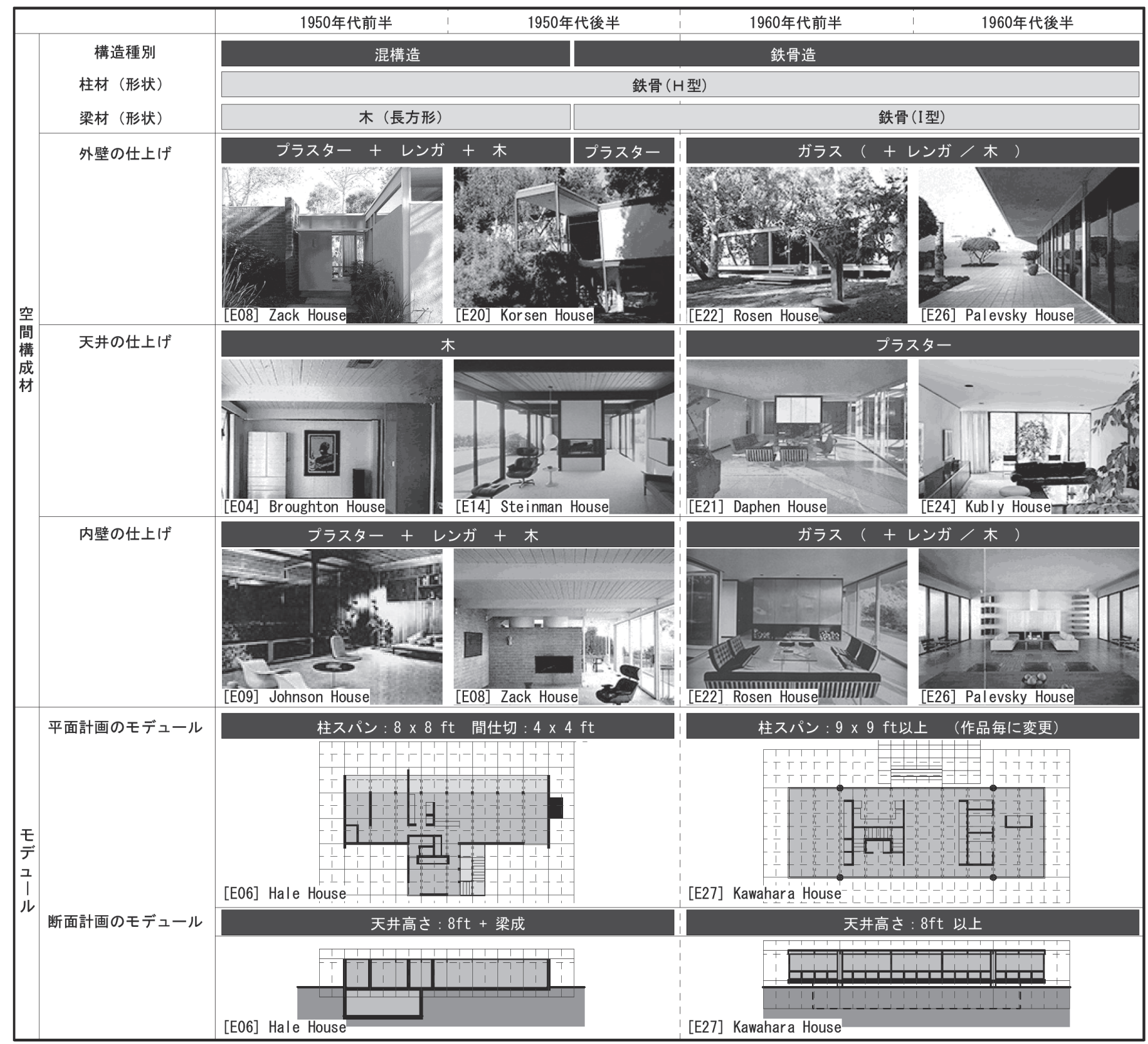


6) Alfonso Perez-Mendez: CRAIG ELLWOOD IN THE SPIRIT OF THE TIME, Gustavo Gili, 2003

7）岸和郎・植田実監修：ケース・スタディ・ハウス，住まいの図書館出版 局， 1997

8）那須聖, 八木幸二,ほか 2 名：「ケース・スタディ・八ウス・プログラム」 に見られる理想住宅 建築家の言説と建築構成の比較を通して, 日本建 築学会計画系論文集，No. 508，pp. 249-255，1998.6

9）山中章江, 川向正人：ケース・スタディ・ハウス・プログラムにおける 「空間的広がり」場所に根差す感覚をもつ「戦後住宅」のキー・コンセ プトとして，日本建築学会計画系論文集，No. 604，pp. 203-210，2006.6

10）山中章江, 川向正人：ケース・スタディ・ハウスにおける「場」の生成 眺 望の中に住まうための手法として, 日本建築学会計画系論文集, №.614, pp. 253-260, 2007. 4

11）前田忠直, 朽木順綱, ほか 3 名：C. エルウッドの 3 住宅における平面の意 味 ケース・スタディ・ハウスにおけるフォーム生成過程の研究 5 , 日本 建築学会大会学術講演梗概集, F-2, pp. 589-590, 2005.9

12）前田忠直, 朽木順綱, ほか 3 名：C. エルウッドの 7 住宅の平面一主室の成 立 ケース・スタディー・八ウスにおけるフォーム生成過程の研究 2 , 日 本建築学会近畿支部研究報告集, pp. 913-916, 2005.9

13）宮下智裕 : 23 Case Study House に関する研究その 2 CSH\#1,\#16 開口部 による外部, 内部空間のつながり, 日本建築学会関東支部研究報告集, pp. 585-588, 1998.2

14）平田拓也, 末包伸吾, ほか 1 名 : クレイグ・エルウッドの建築思想とその 空間構成手法に関する研究—〈rhythm〉〈order〉の関係に着目して日本建 築学会近畿支部研究発表会, pp. 817-820,2011

15) Elizabeth A. T. Smith, Esther McCoy: Blueprints for Modern Living, History and Legacy of the Case Study Houses, Mit Pr, 1989

16) James Steele,David Jenkins, Pierre Koenig: Pierre Koenig, Phaidon Inc. Ltd., 1998

17) Elizabeth A.T.Smith, Julius Shulman, Peter Goessel: CASE STUDY HOUSE THE COMPLETE CSH PROGRAM 1945-1966, TASCHEN, 2002

18) Elizabeth A.T.Smith: Case Study House,TASCHEN, 2006

\section{注}

注 1) 本考察は, 以下の発表をもとに, 再考察を行うとともに新たな知見を 加え再構成したものである，増岡亮, 末包伸吾 : クレイグ・エルウッ ドの独立住宅作品における空間構成と架構形式に関する研究, 日本建 築学会大会学術講演梗概集，F-2, pp. 463-464, 2002.8

注 2）増岡亮, 末包伸吾 : クレイグ・エルウッドの住宅建築の開放性にみる 空間構成の類型とその移行, 日本建築学会計画系論文集, No. 706, pp. 2775-2785, 2014. 12

注 3）参考文献 1)

注 4）架構については，「建物を構成する骨組のこと，部材の組み方により， ラーメンやトラスあるいはそれらの併用などの方式に分かれる（建築 大辞典第 2 版, 彰国社)」とあり，「材を結合して作った構造物（広辞 苑第五版，岩波書店）」といった定義がなされているが，本研究では構 造と, 外部仕上材や内部仕上材の組み方を架構と呼ぶ.

注 5）参考文献 2) に収録されているエルウッドの論文「on architecture」( pp. 153-154, 1966 年) のなかで，彼は構造と形態の関係性にふれ，構 造は空間に秩序や規律，さらにリズムを与え，これらは空間を創出す るうえで重要な要素であると述べている.

注 6）「原則」については「人間活動の根本的な規則. 基本的なきまり（広辞 苑第五版，岩波書店）」といった定義がなされているが，本研究では 空間に与えられる一定の規則を原則と呼ぶ.

注 7）参考文献 2) に収録されているエルウッドの論文「on architecture」( pp. 153-154, 1966 年) より抜粋する.

注 8）参考文献 2)

注 9）参考文献 3)

注 10) 参考文献 4)

注 11) 参考文献 5)

注 12) 参考文献 6)

注 13) 参考文献 7)

注 14)これまで，参考文献 8) 9）10）のCSH に関する先行研究はあるが，エル ウッドに着目した研究は, 認められない.

注 15) 参考文献 11) 12)
注 16) 参考文献 13)

注 17) 参考文献 14)

注 18) エルウッドの作品集や掲載雑誌, カリフォルニア州立工科大学ポモナ 校 (CSPU)にあるアーカイブで資料収集により調査を行った.

注 19） 2001 年 12 月の現地調査とエルウッドのアーカイブで図面・写真の収 集, 2014 年 9 月に現存する分析対象作品を訪問し, 可能なものについ ては内部調査, かつ当時の施主や現在の住人にヒアリングを行った.

注 20) 参考文献 2) 3) 4) 5) 6)

注 21) 柱と梁の構造材, 外部の仕上材, 内部の仕上材を空間構成材とする.

注 22) 主な外部仕上材として, 道路側と外部空間に面する外観は，建築家の 意図が反映されている主要な立面と考え, その範囲の外壁と外構を分 析の対象範囲とする。

注 23) 居間やダイング，キッチンを含む，建築家の意図が反映されている主 要な空間を分析の対象範囲と寸る。また，内部仕上材のうち，床材は 当時の資料が不足と住宅の所有者の変更による改修による当時の状況 が把握できないため分析項目から除いている.

注 24）居間（リビング），ダイニングやキッチン等を含んだ領域とする．分析 にあたって，収集資料の平面図や説明文に居間（リビング）等の表記 がなくとも，居間と推測が可能ならば居間とし，表記が別名であって もそこが住宅において居間的役割をしているならばそこを公室空間に 含む.

注 25)壁やカウンター等の固定家具，暖炉等によって空間を分割するものを 間仕切とし，分析の対象範囲とする。

注 26) 分析対象とする外構は, 公室空間に面した外部空間の床材とする. 公 室とレベル差がある外部空間は対象外とする.

注 27) エルウッドの言説を本文中で使用する際は,「」の表記とする

注 28) 増岡亮, 未包伸吾 : クレイグ・エルウッドの建築思想における主題の特 質とその変遷, Design シンポジウム 2014, pp. 213-216, 2014.11. このなかで，エルウッドの建築に対する言説，自身の建築や空間を分 析し，具体的な方針や手法にいたる言説を抽出し，KJ 法により各項目 を整理し, 構造化を行っている.

注 29）参考文献 2) に収録されているエルウッドの論文「on architecture」（ pp. 153-154, 1966 年) より抜粋する

注 30）参考文献 2)に収録されているエルウッドの論文「on architecture」( pp. 153-154, 1966 年) のなかで，構築部の装飾について彼は次の $4 つ$ 要素で構成されていると述べている。

(1)構造はフレームやアーチ，シェルのリズミカルな表現の装飾

(2)素材は, テクスチャーと色のリズミカルな強調の装飾

(3)形態はマッス，ボリュームと線のリズミカルな相互作用の装飾

(4)奥行きは光と影のリズミカルな変化と喜びの装飾

注 31）参考文献 2)に収録されているエルウッドの論文「on architecture」( pp. 153-154, 1966 年) より抜粋する

注 32）装飾について，4つの要素からなることは注 30)で述べた. エルウッ ドはこれらの要素にはリズミカルな構成が必要であると考えていた。

注 33）参考文献 2）に収録されているエルウッドの論文「on architecture」( pp. 153-154, 1966 年) より抜粋する.

注 34）断面図の高さは，矩計図等がない作品に関しては，参考文献 2）3）4～ 5)6)の資料に加え, アーカイブと現地調査により高さを判断した. 


\title{
SPACE AND ITS COMPOSITION OF CRAIG ELLWOOD'S RESIDENTIAL BUILDINGS FOCUSING ON MATERIAL AND MODULAR SYSTEM
}

\author{
Ryo MASUOKA* and Shingo SUEKANE** \\ * Grad. Stud., Graduate School of Engineering, Kobe University. \\ NTT FACILITIES, INC, M.Eng. \\ ** Prof., Graduate School of Engineering, Kobe University, Dr. Eng.
}

This research is part of investigates the features of the architecture of Craig Ellwood, a leading architect of the American West Coast post-WWII and the creator of Case Study Houses \#16 (1952), \#17 (1956), and \#18 (1958), and focuses on the space and composition of his residential buildings. In previous research, focusing on the openness of Ellwood's residential buildings, mainly clarified the characteristics of site composition and plan composition.

These characteristics of Ellwood's architecture are found primarily in the creation of spaces that emphasize frameworks of steel. Though his choice of materials and construction methods changed with time, the basic principle from which Ellwood's forms derived remained unchanged, unaffected by the passing time. It can be said that this principle tries to bestow a fixed rule upon a space by frameworks. By investigating at types and transformation of materials and modular system that Ellwood used, the research intend to clarify some of the architectural characteristics that are particular to his frameworks. In past studies on Ellwood, he is judged mainly on CSH \#16, with many studies grasping it within the entirety of $\mathrm{CSH}$, or focusing on a single section of his works. From the author's point of view, it is insufficient to generalize about the quality of Ellwood's architecture based on his CSH works alone. Therefore, this research goes systematically through the entirety of Ellwood's activities, generally looking at their characteristics and, including those transitions, tries to precipitate their essence, something do not think has been done before. By the time of his death in 1992, Ellwood had planned 58 residential buildings. Of those, 38 works were built, mainly from the 1950s to the early 1960s. This study focuses on the residential building projects that were central to Ellwood's activities, and has as its subject the analysis of 28 works that a survey of the analytical materials showed to have complete documents. In this research of Ellwood's residential buildings, analysis deals with 28 works and structure, primary exterior finishing materials, primary interior finishing materials, modular system on both plan and section.

The results of this analysis revealed the following. There are two large trends in the 1950s and 1960s for Ellwood's materials and modular system. In the 1950s, when standardization of construction lead to uniform spaces, he countered this trend by spatially arranging materials with texture in one modular system and controlling them with the exposed beams. Through this, he created an architecture that gave rhythm to space. In the 1960s, Ellwood used various column spans, defining the appearance of buildings by exposing beams and columns on the outside, making for compositions that gave rhythm to the outside. In other words, Ellwood shifted the organization of his frameworks from the interior to the exterior, and facilitated recognition of modular system by this expression. Ellwood transferred a principle of the spatial creation in this way by giving rhythm to space. In this way, by analyzing materials and modular system, this research clarifies how these bring a fixed rhythm to the frameworks and how they organize spaces. 